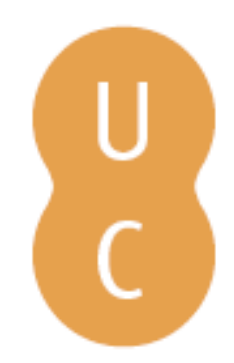

\title{
nommalina
}

\section{A sabedoria estóica: paixão e razão na Medeia de Séneca}

Autor(es): $\quad$ Serra, José Pedro

Publicado por: Imprensa da Universidade de Coimbra; Universidad de Valladolid

URL

persistente: URI:http://hdl.handle.net/10316.2/32303

DOI: $\quad$ DOI:http://dx.doi.org/10.14195/978-989-26-0472-5_6

Accessed : $\quad$ 26-Apr-2023 10:56:40

A navegação consulta e descarregamento dos títulos inseridos nas Bibliotecas Digitais UC Digitalis, UC Pombalina e UC Impactum, pressupõem a aceitação plena e sem reservas dos Termos e Condições de Uso destas Bibliotecas Digitais, disponíveis em https://digitalis.uc.pt/pt-pt/termos.

Conforme exposto nos referidos Termos e Condições de Uso, o descarregamento de títulos de acesso restrito requer uma licença válida de autorização devendo o utilizador aceder ao(s) documento(s) a partir de um endereço de IP da instituição detentora da supramencionada licença.

Ao utilizador é apenas permitido o descarregamento para uso pessoal, pelo que o emprego do(s) título(s) descarregado(s) para outro fim, designadamente comercial, carece de autorização do respetivo autor ou editor da obra.

Na medida em que todas as obras da UC Digitalis se encontram protegidas pelo Código do Direito de Autor e Direitos Conexos e demais legislação aplicável, toda a cópia, parcial ou total, deste documento, nos casos em que é legalmente admitida, deverá conter ou fazer-se acompanhar por este aviso.

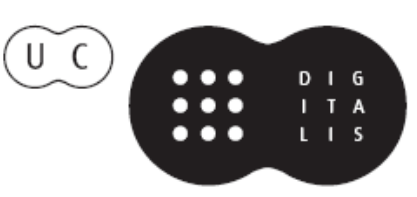


Emilio Suárez de la Torre

Maria do Céu Fialho

(Coordinadores)

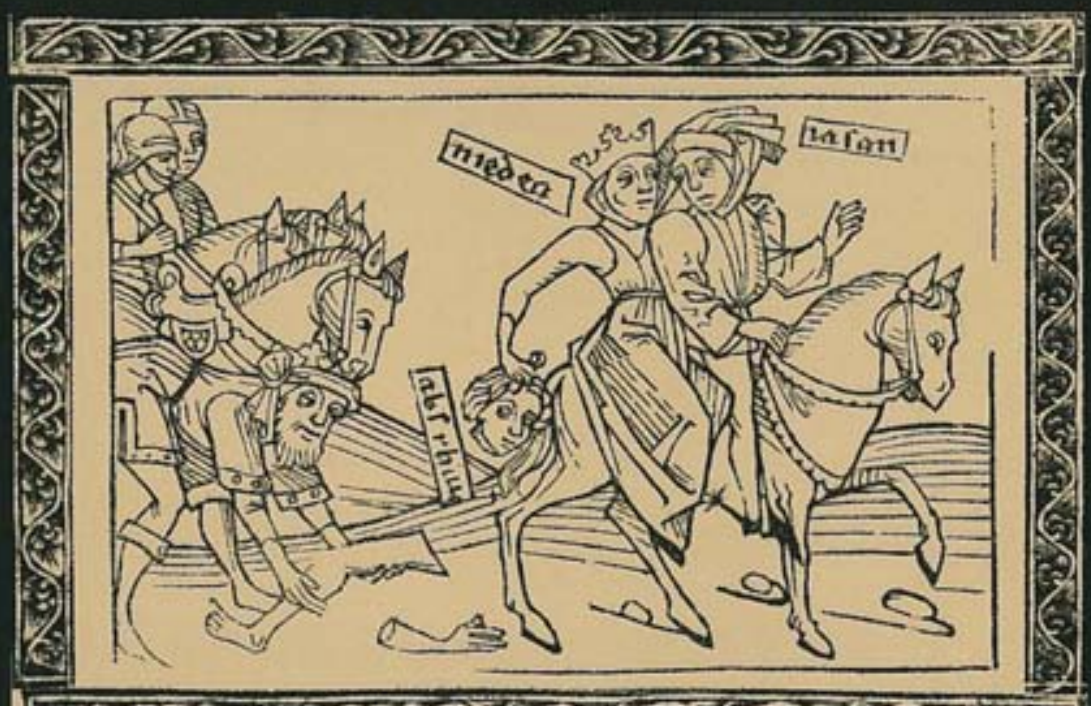

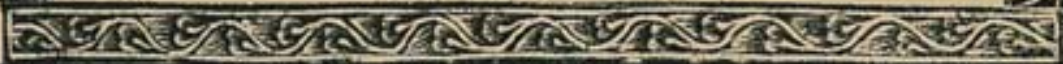

\section{BAJO EL SIGNO DE MEDEA}

\section{SOB O SIGNO DE MEDÉIA}




\section{A sabedoria estóica: paixão e razão na Medeia de Séneca}

José Pedro SERRA

Universidade de Lisboa

Pelos contornos de uma total entrega a um homem, ainda que sem regra e desvairada, pelos traços de uma paixăo exacerbada e desmedida, convulsivamente vivida, ou pelos sinais de revolta de uma marginal voz feminina numa sociedade por homens governada, por estes ou outros motivos, năo seria difícil encontrar ecos de uma benévola compreensão ou até de simpatia pela mítica figura de Medeia ${ }^{(1)}$. Impensada simpatia ou apressado repúdio, assentes numa estrita ressonância emotiva, nâo nos situam, porém, na adequada perspectiva para a interpretaçăo da Medeia de Séneca, afastando-nos do pensamento filosófico do autor, indispensável à apreensão do sentido último da tragédia. Indissociável da doutrina estóica que explícita e implicitamente lhe serve de pano de fundo e de inspiraçăo, a acção dramática da Medeia, mais do que uma lírica expressāo dos tormentos amorosos, arrasta consigo o desenho e a defesa de um "regime de vida", de um modelo de comportamento. Sendo o estoicismo a filosofia subjacente ao teatro de Séneca, e a virtude um dos principais temas das tragédias, é justamente pelo estoicismo que devemos começar a nossa análise.

(1) Para uma benévola interpretaçao da figura de Medeia na tragédia de Séneca, indico apenas o belo texto de Walter de Medeiros, "A Donzela no Carro do Sol. Os Caminhos do Abismo e da Redençăo na Medeia Senequiana", Medeia no Drama Antigo e Moderno, Actas do Colóquio de 11 e 12 de abril de 1991, Coimbra, 1991, pp. 45-56. Neste texto, ergue-se e domina a figura de uma donzela, saudosa da inocência passada, abandonada, frágil e vulnerável, que a tudo renunciou por amor. 


\section{SÉNECA E O ESTOICISMO}

Desde cedo o estoicismo ${ }^{(2)}$ exerceu uma determinante influência na formação de Séneca. Jovem ainda, interessado na retórica e na filosofia que sentia constituírem a sua verdadeira vocaçăo, Séneca foi por Átalo ${ }^{(3)}$, um dos seus mestres, iniciado na doutrina estóica e nas exigências da sapientia, único caminho que conduz a uma vida virtuosa. Atraído pelo pensamento desta Escola, Séneca tornou-se na mais importante figura do estoicismo imperial e os seus escritos - e nāo apenas as obras de conteúdo moral ${ }^{(4)}$.

(2) O estoicismo deve o seu nome ao local onde o seu fundador, Zenão, proferia as palestras - a stoa poikile, o pórtico decorado com as pinturas de Polignoto, em Atenas, motivo pelo qual a doutrina é também designada por Escola do Pórtico. É hábito distinguir trếs fases na cronologia do estoicismo: o estoicismo antigo, o estoicismo médio, o neo-estoicismo ou estoicismo imperial. O estoicismo antigo abrange um período que vai dos finais do século IV a.C. até ao início do século II a.C. e engloba, entre outros, o já citado Zenảo de Cício, Cleantes, sucessor de Zenấo na direcçăo da Escola, e Crisipo, discípulo de Cleantes e também seu sucessor à cabeça da Escola. No estoicismo médio, que abrange os séculos II e I a.C., destacam-se os nomes de Panécio de Rodes e de Posidónio de Apameia. Finalmente, o neo-estoicismo ou estoicismo imperial, que se estende ao longo dos séculos I e II d.C., além de L. Aneu Séneca, Musónio Rufo, Epicteto, figuras principais, engloba ainda os nomes de Varrāo, Cícero, Floro e Tácito. Ver José Pedro Serra, s.tu. Estoicismo, in Maria Helena Urefía Prieto, Dicionário de Literatura Latina, Lisboa, Ed. Verbo, 2006. Sobre os estóicos e o estoicismo ver Stoicorum ueterum fragmenta, 4 vols., Leipzig, 1903-1924; I frammenti degli stoici antichi, trad. e annot. da N. Festa, I. Zenone. II. Aristone, Apollofane, Erillo, Dionigi d'Enaclea Persea, Cleante, Sfero, Bari, 1932-1935; Panartii Rhodii fragmenta, Leida, 1952; Il pensiero stoico ed epicureo, Florença, 1958; I frammenti degli stoici antichi, trad. da R. Anastasi, Padova, 1962; Les stö̈ciens, textes trad. par E. Brćhier, Paris, Bibliotèque de la Pléiade, 1962; Stoa und stoiker. Die Gründer, Panaitios, Poseidonios, eingeleit. und übertr. von M. Pohlenz, 2. Aufl, Zürich, 1964; Ludwig Edelstein, The Meaning of Stoicism, Cambridge, Mass., Harvard University Press, 1966; J.M. Rist, Stoic Philosophy, Cambridge, 1969; J.M. Rist (ed.), The Stoics, Berkeley and Los Angeles, 1978; Jean Brun, O estoicismo, trad. de Joăo Amado, Lisboa, Ed. 70, 1986; K. Algra, J. Barnes, J. Mansfeld, M. Schofield (eds), The Cambridge History of Hellenistic Philosophy, Cambridge, Cambridge University Press, 1999; Brad Inwood (ed.), The Cambridge Companion to the Stoics, Cambridge, Cambridge University Press, 2003.

(3) Discípulos de Quinto Sêxtio, filósofo que na época de Augusto fundara um movimento de cariz estóico e neopitagórico, Sócion, Átalo e Papírio Fabiano foram os mestres que mais influenciaram Séneca. Leiam-se, por exemplo, as consideraçōes que, a propósito do ensino de Áralo, Séneca profere em Epistulae morales ad Lucilium, 108. Para uma apreciaçăo conjunta da vida e da obra de Séneca, nas suas múltiplas relaçóes, ver Manuel Antunes, "Séneca, Filósofo da Condição Humana" in Grandes Contemporâneos, Lisboa, 1973, pp. 1120 (reimp. de um artigo publicado na Brotéria, Outubro, 1965, pp. 334-341); Pierre Grimal, Sénèque ou la conscience de l'Empire, Paris, Les Belles-Lettres, 1978 (reeditado posteriormente, Paris, Fayard, 1991); Id., Sénèque, Paris, P.U.F., 1981; Maria Cristina Pimentel, Séneca, Lisboa, 2000.

(4) Ver, por exemplo, as consideraçóes feitas a propósito dos tremores de terra em "De Terrae Motu", Nat. Qaest., Livro VI. Sobre o tema veja-se José Pedro Serra, "A Antiguidade Clássica e os tremores de terra: mythos e logos", in Helena Carvalhăo Buescu e Gonçalo Cordeiro (Coord.), O grande terramoto de Lisboa. Ficar diferente, Lisboa, 2005, pp.109-136. 
reflectem os princípios filosóficos da doutrina. Provavelmente escritas, na sua maioria, nos últimos anos de vida - de acordo com o testemunho de Tácito, Séneca ter-se-ia dedicado a compor obras poéticas por volta de 61 ou $62^{(5)}$ —, as tragédias náo escapam a este enquadramento: sāo a criaçấo de um homem maduro, acima de tudo preocupado com o bem moral, crítico relativamente àqueles que olham e cultivam a literatura apenas pelo ornamento fácil, pelo deleite de uma aparência bela suportada em palavras que năo orientam as consciências, nem revelam a virtude.

Incide o estoicismo sobre três áreas distintas do saber, a lógica, a física e a ética, procurando, a partir delas, estabelecer um sistema harmonioso e coerente, uma espécie de global saber sobre as coisas humanas e divinas. Com o tempo, porém, relegadas a lógica e a física para plano secundário, foram as questôes éticas que ganharam relevo e ainda que alguns neguem à doutrina o estatuto próprio de filosofia, restringindo-a a uma retórica $\mathrm{e}$ a uma parenética ${ }^{(6)}$, o estoicismo impôs-se na história do pensamento como um movimento de interiorizaçāo e de aprofundamento da consciência, indissociável do contínuo exercício de um "regime de vida" delineado numa sábia orientaçăo perante as coisas e os seres. Por consequência, nāo é de estranhar que seja uma preocupaçăo e um primordial interesse éticos que se encontrem também expressos nas tragédias. Mas como se vincula esta preocupaçāo às tragédias, particularmente, à Medeia? E qual a noção a partir da qual podemos estabelecer esse vínculo, pondo a descoberto essa intencionalidade primeira? É a noção de "paixāo" que, desempenhando um papel decisivo na concepçáo da moral estóica e ocupando um lugar central na construçẩo das tragédias, nos permite estabelecer a ponte entre a doutrina e a obra literária. Deste cruzamento entre o Séneca filósofo e o Séneca poeta resulta a clarificaçâo não apenas da finalidade pedagógica da sua tragediografia, como também dos pressupostos teóricos que a justificam. "Paixăo", do

(5) Cf. Tácito, Annales, XIV, 52. Por alguns indícios que poderiam reflectir a assinatura do acordo entre Roma e os Partos, em 63, André Arcellaschi data a criaçăo da Medeia entre 63 e 64 (Médée dans le théatre latin d'Ennius à Sénèque, Rome, Collection de l'École française de Rome, n. 132, 1990). A data da criação das tragédias é controversa. Săo normalmente apontados os seguintes "momentos": os anos de exilio passados na Córsega; os derradeiros tempos do período neroniano, acompanhando o desejo de Nero de subir à cena; ou, mais provavelmente, os últimos anos passados num fértil e criativo retiro. Ver, Maria Cristina Pimentel, op. cit., pp. 55 ss.; Pierre Grimal, Sénèque, pp. 84 ss.; Giuseppe Gilberto Biondi, Séneca. Medea. Fedra, premessa altesto, introduzione e note de Giuseppe Gilberto Biondi, trad. di Alfonso Traina, Milano, BUR, 2004 (13. ed.), pp. 32-33.

(6) Como ilustraçăo de uma posiçăo que nega ao estoicismo o estatuto de filosofia, veja-se Hegel, Leçons sur l'histoire de la philosophie, trad. par Pierre Garniron, tome IV, Paris, 1975. p. 644 . 
latim passio, remete para patior ${ }^{(7)}$, verbo de etimologia desconhecida que,

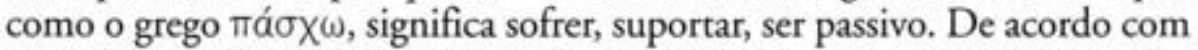
o caminho indicado pela etimologia, a "paixão" é, entāo, algo que se sofre, que se suporta passivamente - um affectus, para usar um termo clássico. Esse affectus, ao afectar a alma, desencadeia nela uma alteraçăo, uma perturbaçáo, um movimento que, divergindo em sentido oposto à Razăo, assume contornos tumultuosos, mórbidos e desordenados. É pelo uso da sua ratio, da sua razão, que o homem coincide e se conforma com o Logos, tal "alma do mundo" que ordena a realidade, que tudo governa e a tudo preside. Esta con-formação, de alcance ontológico e de consequências éticas, impốe uma decisiva distinçăo de cariz antropológico entre a alma racional, a parte constitutiva do homem considerada hierarquicamente superior, e os instintos, os impulsos, os desejos, as paixóes. Só o soberano, continuado e vigilante exercício da razảo, entendido como bem específico do homem, elemento que o distingue dos outros seres vivos, possibilita a efectiva realizaçáo da virtude, da qual resulta a uita beata, a vida feliz. Embora distintas na forma, substancialmente, as expressōes "viver segundo a virtude", "viver segundo a razâo" e "viver segundo a natureza" identificamse, uma vez que "viver segundo a natureza" năo significa estar submetido a necessidades básicas ou a apetites e satisfazê-los, mas antes viver de acordo com o que é especificamente humano e permite ao homem conformar-se com a ordem última do real, isto é, viver segundo a razăo; neste acordo consiste precisamente a uirtus, a virtude, e por isso viver segundo a natureza, a razáo ou a virtude săo uma e a mesma coisa.

$\mathrm{Na}$ sua concretizaçāo, a vida do sapiens, do sábio, traduz-se naquilo que os gregos designam por ámáteıı e que Séneca designa por tranquillitas animi, a tranquilidade da alma. A tranquillitas animi nāo é a expressão de uma indiferença distante, nem de uma musculada e forçada coragem perante os sofrimentos e as contrariedades; em vez disso, é ela a expressăo de uma serenidade fundada no recolhimento interior que, propiciando um afastamento das circunstâncias do mundo, impede sejamos por elas triturados, num remoinho de dores, frustraçōes e fátuas e ilusórias satisfaçōes. Nesta tranquilidade, cujos contornos desenhados são os de uma digna impassibilidade, o homem, em lugar de escravo das paixōes, de agrilhoado servo aos desmandos das fúrias submetido, torna-se no sereno cavaleiro que, imperturbável, cavalga as inconstâncias da fortuna, os reveses da sorte. Os males do mundo năo o afectam.

(7) Para a etimologia de passio, ver A. Ernout et A. Meillet, Dictionnaire thmologique de la langue latine. Histoire des mots, Paris, 1979, s.u. Patior. 
Neste cenário, levantam-se duas questốes de decisiva importância. Como compreender o processo mediante o qual o homem se liberta das paixōes ou, dito de outro modo, de que forma pode o homem subtrair-se às garras das paixōes, evitando assim cair no vício? $\mathrm{Na}$ sequência da pergunta anterior, é igualmente legítimo inquirir, aliás com um misto de surpresa e de desconfiança, acerca da motivaçấo última que terá levado Séneca, homem tăo absolutamente concentrado na questâo da virtude, a compor tragédias onde se apresentam exemplos de táo arrebatadas paixōes e desconcertos da alma. Subjacente a este inquérito, encontram-se todas as questốes relacionadas com o estatuto da poesia e a sua função, os seus benefícios e desvantagens, o alcance da sua dimensáo educativa ${ }^{\left({ }^{(8)}\right.}$.

Debrucemo-nos, entāo, sobre a primeira questâo. A compreensāo do processo mediante o qual o homem se pode libertar das paixōes depende, em última análise, do facto de nelas se reconhecer, ou não, a presença de um elemento cognitivo. Sinteticamente, poderia o problema ser assim equacionado. Para alguns, as paixōes nada contêm de cognitivo ${ }^{(9)}$. Baseados na doutrina platónica da tripartiçáo da alma - onde se

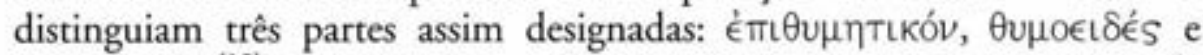

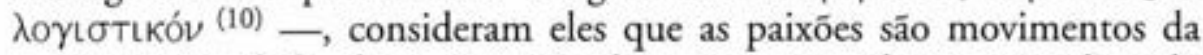
parte irracional da alma, aí originados, năo contendo nem implicando qualquer juízo. Deste modo, sendo estranhas aos juízos, deles nāo dependendo nem neles se suportando, as paixōes, manifestaçōes irracionais, não se deixam controlar nem domesticar pelas capacidades da razão e pelo que a partir da razăo pode ser fundado. O que é estranho à razăo, pela razăo nāo pode ser domado. Tumultuosos movimentos da parte irracional da alma, as paixóes só podem, entáo, ser controladas mediante hábitos exigentes e uma disciplina ascética, ou por outras

(8) Antes de Séneca, a questão da funçăo da poesia e a sua relaçăo com a educaçăo tinha sido já vastamente tratada. Basta recordar que Platáo expulsa os poetas dramáticos da república ideal. Cf. Rep., 398a-b. Nāo deverăo os estóicos seguir aquele exemplo, opondo-se à ilustraçăo de vícios nas representaçōes dramáticas, cuja influência, sobretudo na juventude, conforme denunciava Platão, pode ser demolidora?

(9) É o caso, por exemplo, de Posidónio. O estoicismo tem representantes de ambas as perspectivas; opondo-se, neste particular, a Posidónio, encontram-se Crisipo, Epicteto e Séneca. Para o tema que agora nos ocupa, ver os clarividentes artigos de Martha Nussbaum, "The Stoics on the Extirpation of the Passions", Apeiron, 20, 1987, 129-177; "Poetry and the Passions: two Stoic Views", in Passions and Perception: Studies in Hellenistic Philosophy of mind: proceedings of the fifth Symposium Hellenisticum, (eds) J. Brunschwig and Martha C. Nussbaum, Cambridge, 1993, pp. 97-149.

(10) Cf. Rep., 442a-445; 588b-589a; 606a-d. A verdade, porém, é que as duas perspectivas se reclamam de Platáo. Ver Martha Nussbaum, "Poetry and the Passions: two Stoic Views", pp. 101 ss. 
técnicas e meios que, como a música, se relacionem directamente com a sede de onde emanam. Nāo ao texto, nem ao juízo, nem à doutrina, é à música que pedagogicamente se deve recorrer para aplacar as paixóes.

Outros, porém, entendem que no âmago da paixão está sempre uma estrutura cognitiva, um juízo, condiçâao necessária à constituiçāo da paixāo. Deixando agora de lado a questâo de saber se a paixāo se identifica totalmente com o juízo, ou se este é apenas um elemento ao qual se soma um outro irracional, importa salientar que, nesta perspectiva, a paixão depende de uma crença, de um assentimento dado a uma aparência, enfim, de um juízo falso. Este juízo arrasta consigo uma avaliação relativa a algum "bem" exterior ou a circunstâncias exteriores que, estando fora do nosso domínio, nos deixam em situação de grande vulnerabilidade. Vejamos o exemplo da paixẫo de Medeia; o insano amor de Medeia, que a levou a trair o pai e a matar o seu irmão, o assanhado ciúme, que a conduziu à desvairada vingança, originam-se na convicção de que só na "possuída" presença de Jasão poderá ter uma vida feliz. Implícito nesta conviç̧ăo, está o juízo segundo o qual a ausência de Jasăo, o abandono próximo de Jasáo, por ela nâo controlado e perante o qual está como vítima passiva às măos das circunstâncias, constituirá para a filha de Eetes uma próxima privaçăo de um bem, uma desgraça de onde jorrará um caudal de males que sobre ela cairá ${ }^{(11)}$. E por isso a sombra da vingança se ergue e a măo infanticida ganha corpo e forma. Compreendesse Medeia que só a independência perante as coisas exteriores, só a vida segundo a razâo the permitiria vencer as tentaculares oscilaçōes da fortuna, e a sua doentia inquietaçáo transformar-se-ia em serenidade interior. Deixe de esperar por Jasăo e muitos dos males se dissiparão ${ }^{(12)}$.

$\mathrm{O}$ exemplo anterior permite-nos verificar que as paixôes, colocando-nos sobre a alçada de coisas exteriores que nāo dominamos, nos deixam à mercê dos acontecimentos - precisamente o contrário do ideal estóico da tranquillitas. Um falso juízo, no seio do qual se outorga uma importância e um valor ao que de facto o nāo tem, origina estes doentios movimentos da alma. Se, porém, mediante o cálculo e o exercício da razáo, se alterar este juízo, de forma a atribuirmos a fugacidade ao que é fugaz e a constância ao

(11) As paixóes estão todas muito próximas umas das outras, e todas dependem de uma avaliaçăo das circunstâncias externas. As figuras fundamentais nesta avaliaçăo sāo bom / mau, presente / futuro. Assim, a) julga-se que algo é bom no presente; b) julga-se que alguma coisa é boa no futuro; c) julga-se que algo é mau no presente; d) julga-se que alguma coisa é má no futuro.

(12) Vai neste sentido o justo conselho, do ponto de vista estóico, dado por Epicteto a Medeia. Cf. Disc, II, 17, 22. 
que é constante e inalterável, então, nẩo apenas estaremos livres das paixōes e ao abrigo da caprichosa roda da fortuna, como ainda viveremos uma vida virtuosa e feliz, que nenhuma contingência poderá vir a abalar. As tragédias dissolvem-se no recto juízo. Nesta perspectiva, que é a de Séneca, o que está em causa não é acalmar ou aplacar as paixôes, mas erradicá-las, alterando os juízos que as suportam. O tratamento das paixổes deve, pois, consistir na transformaçăo radical do modo de olhar o mundo e a vida, e é, por isso, primordialmente um acto de razão. Assim sendo, compreende-se que os adeptos desta tese valorizem, na arte poética, o texto em detrimento da música, o conteúdo em detrimento do ritmo ${ }^{(13)}$.

Esta alteraçăo da perspectiva e do juízo a que nos referimos impōem, na legítima e desejável aspiraçăo de atingir a sapientia, um grande empenhamento na orientaçâo do espírito, uma especial vigilância no exame de consciência, uma rejeição da communis opinio — só a reflexão filosófica nos permite a benéfica desconfiança crítica relativamente à opiniāo vulgar -, uma concentraçāo nas questōes decisivas. Neste sentido, a meditatio mortis, constitui um momento determinante na demanda da virtude. Na meditaçáo da morte e pela meditaçáo da morte, desliga-se o homem das coisas perecíveis, cedo ou tarde votadas à destruiçẩo, aprendendo a ter com elas uma relação livre porque as possui como se as não possuísse, porque com elas lida como coisa que the nâo pertence para sempre, mas como coisa que a fortuna temporariamente emprestou. E neste ascetismo descobre a serenidade, a liberdade, a virtude. Coloca-se, porém, uma pergunta relevante: esta modificação cognitiva, intelectual, é suficiente para comprometer o homem no caminho da virtude, arrastando necessariamente com ela a transformaçāo do seu comportamento? Por outras palavras, bastará inteligir para agir bem ou, como o indica os versos de Ovídio a propósito de Medeia, é possível ver e sancionar o bem, mas praticar o mal ${ }^{(14) ?}$ ? Com tal pergunta, introduz-se aqui o complexo tema da vontade. Não constituindo o sistema teórico, mas a regra de vida, a

(13) Ver José Pedro Serra, Pensar o trágico. Categorias da tragédia grega, Lisboa (no prelo). Ambas as perspectivas concordam que a razäo deve impor o seu crivo aos afectos, mas divergem no modo de o conseguir.

(14) uideo meliona proboque deteriona sequor

Cf. Ovídio, Met., VII, 20-21. Para o comentário a estes versos, integrando-os na problemática estóica e mais concretamente no pensamento de Séneca ver J. A. Segurado e Campos, "Ratio e uoluntas no pensamento de Séneca", Classica. Boletim de Pedagogia e Cultunt, 22 (Occidua plaga. Actas do Colóquio Internacional sobre o Ensino do Latiml), 12-13 de Dezembro de 1996, Faculdade de Letras de Lisboa), 1997, pp. 79-92. Para a questāo da vontade ver ainda André-Jean Voelke, L'idée de volonté dans le stö̈cisme, Paris, 1973; Albrecht Dihle, The Theory of Will in Classical Antiquity, Berkeley. Los Angeles. London, 1982. 
preocupaçăo fundamental de Séneca, a noção de uoluntas apresenta flutuaçôes de significado, por vezes até incongruências, das quais decorrem múltiplas interpretaçóes, nomeadamente no que diz respeito à contribuição do pensador de Córdova para a noção filosófica de vontade. Apesar disto, porém, e para o que nos interessa, é possível desenhar claramente a natureza das dificuldades a que este conceito procura dar resposta e o modo como ele se insere e articula no processo de libertaçáo dos afectos.

É conhecida a solução intelectualista apresentada pela filosofia socrático-platónica para a questâo do erro moral. Partindo do suposto que ninguém se engana propositadamente e que cada um decide de acordo com o que julga ser-lhe benéfico, qualquer que seja a índole deste bem, Platăo entendia que o erro resultava sempre de uma ignorância. A intelecçāo do bem, pelo fulgor nele próprio contido, obriga necessariamente a uma conduta virtuosa; o deleite nas paixōes resulta de uma ignorância, de uma inversão na compreensão da hierarquia do real. Conhecer o bem implica agir bem. Deste modo, nẩo sendo possível pensar a acçăo sem que esta esteja em consonância com o saber que a inspira, elimina-se, ou melhor, impede-se que surja, porque nem pensado é, o hiato e a possível divergência entre pensar e agir. Embora sem negar a influência platónica que nele germina, é precisamente neste ponto que o estoicismo introduz uma fractura, uma dissidência. Rasgando um novo trilho na compreensão da acçăo ${ }^{(15)}$, os estóicos não dão como segura e necessária a concordância entre a intelecçăo e o comportamento, admitindo que um sobressalto, uma desarmonia se pode erguer entre ambos. Com a admissão de uma discordância entre pensar e agir, torna-se necessária a referência a uma capacidade que permita unificar o pensamento e a acçáo, assegurando que a intelecção se concretiza no acto. Essa capacidade é a uoluntas. $\mathrm{O}$ uso que Séneca faz do termo "vontade" é flutuante e nẩo sistemático, acolhendo múltiplos sentidos e nem sempre conciliáveis ${ }^{(16)}$, sem que tal facto, porém, nos impeça de atingir o alcance do problema. Seria erróneo supor que a vontade dispensa o recto juízo, uma vez que, sem ele, a vontade é cega; só o juízo denuncia as ilusōes e as falsidades que derivam da incorrecta

(15) Nem podemos esquecer que indícios de uma distância entre pensar e agir se encontram já no teatro de Eurípides, por exemplo no Hipólito e na Medeia, nem podemos afirmar que a vontade é um conceito que se deve totalmente ao estoicismo. Parece ser mais justo afirmar que o estoicismo desenvolveu e aprofundou esta complexa noçắo.

(16) Por vezes a "vontade" parece ser sinónimo de indicium, outras vezes parece ser uma força em tensăo; umas vezes parece ser algo próprio do homem, outras vezes o termo tem uma tal extensăo que parece abarcar o instinto de conservaçăo. Não sendo aqui o local próprio para as analisar, remeto para André-Jean Voelke, op. cit., pp. 161-190. 
apreciação das circunstâncias, das coisas exteriores. Auxilia-nos isto a compreender por que motivo, em alguns passos dos textos de Séneca, a vontade parece ser apenas uma continuação da cogniçâa, posição que tende a aproximar-se, quase coincidentemente, de Platâo e do antigo estoicismo. $\mathrm{Se}$, todavia, năo apreciarmos o problema exclusiva e totalmente a partir da perspectiva intelectualista, compreenderemos que a vontade é isso que está na tensăo do arco que vai do juízo ao acto, e que só ela permite assegurar a idealizada harmonia entre ajuizar e agir, na qual se funda a virtude, a vida do sapiens. A uoluntas é uma tensão, uma força da alma que permite enraizar a verdade do juízo na experienciada virtude do acto. Como, contudo, nada há que garanta definitivamente o prolongamento da verdade do juízo na rectidão moral da acçáo, o exercício da vontade representa um continuado, ascético e vigoroso esforço no propósito de agir segundo a razăo. Só a firme disciplina no exercício da vontade permite erradicar as paixōes. Em última análise, é a constância da uoluntas - o querer sempre as mesmas coisas e o não querer sempre as mesmas coisas - que nos permite aproximar ou, mais raramente, realizar o modelo ideal do sábio estóico: ser concordante consigo próprio, ser ele próprio em todos os seus actos, habitar no acordo entre pensar e agir. São estas as palavras de Séneca num muito citado passo das Epistolae ${ }^{(17)}$ :

"Em suma, deixando as antigas definiçōes de sabedoria e abarcando numa fórmula todo o ciclo da vida humana, acho que seria bastante dizer isto: a sabedoria consiste em querer, e em nâo querer, sempre a mesma coisa. Não é necessário acrescentar, como condiçáo, que devemos querer o que é justo, porque só é possivel querer sempre a mesma coisa se essa coisa for justa".

As consequências das afirmaçōes anteriores năo săo irrelevantes para a compreensăo das tragédias senequianas. Mediante a introdução da noção de vontade, colocados perante a possibilidade de se entregarem às paixōes ou delas se expurgarem mediante uma férrea disciplina - e para Séneca năo há paixōes que a disciplina não possa vencer —, as personagens da tragédia estấo pessoalmente comprometidas e responsabilizadas no destino que sobre elas se abate. É certo que nem as tragédias de Ésquilo e Sófocles representavam o homem como um mero títere às mãos dos deuses e do destino. Mesmo quando sujeitos à àvá $\gamma \kappa \eta$, a necessidade convocava-os

(17) Cf, 20, 5. O texto das Epistulae Monales ad Lucilium constitui um dos textos fundamentais para a compreensão do estoicismo de Séneca. Para uma apresentaçáo genérica da obra ver José António Segurado e Campos, Lúcio Aneu Séneca. Cartas a Lucilio, trad., prefácio e notas de J.A. Segurado e Campos, Lisboa, 1991, pp. V-LIV. É deste autor a tradução apresentada. 
para uma resposta; a consciência da fatalidade de algum modo a altera e por isso náo pode o homem confundir-se com a pedra bruta que a sofre. Ainda assim, no teatro de Séneca, o herói trágico surge mergulhado na sua responsabilidade, na sua culpa, por ter falhado no exercício da vontade e, por isso, na virtude ${ }^{(18)}$.

Antes de nos debruçarmos sobre a segunda questāo acima referida - o paradoxo, e a motivaçáo nele escondida, que leva um homem tăo preocupado com o bem moral a pôr em cena tâo graves exemplos de vício importa antes observar como se erguem e evoluem as paixōes na Medeia.

\section{MEDELA E AS PAIXŌES}

A reflexâo anterior, supondo e aceitando que o tema das paixốes ocupa lugar de relevo na obra de Séneca, orienta a leitura e a interpretaçăo das suas tragédias no sentido de se observar a forma como as paixōes se erguem, de analisar os seus desenvolvimentos e de meditar nas consequências que delas derivam. Importa, pois, verificar agora o modo como se apresentam as paixōes na Medeia, que roupagens as vestem, a que actos, desenvolvendo-se e cumprindo-se, conduzem. O primeiro sinal da desordem e violência das paixōes, tal como se mostram na Medeia, encontra-se desde logo no vocabulário que as expressa. Desde o início até ao final, generalizadamente e de forma obsessiva, o leitor, ou o espectador, é introduzido numa acçăo moldada por um vocabulário de violências e excessos, de crimes, ódios e desvarios. As personagens presentes nessa acçăo săo movidas por um furor, por uma ira, por um impetus, por um odium que florescem em crimina, em nefas, em scelera. Este horizonte de desordem recortado por palavras brutais, esteja ele expresso mediante a referência a um passado criminoso ou mediante a própria representaçăo dos crimes, adequa-se particularmente bem a Medeia, não apenas pelo seu comportamento, mas também por quem ela é. Filha do rei da Cólquide, Eetes, ele próprio filho de Hélio e irmẩo de Circe, Medeia, que assim tem com esta laços familiares, é a feiticeira, a mulher com artes mágicas capaz de invocar e manipular

(18) Para distinguir o logos estóico do logos grego e do logos cristăo, são sugestivas as palavras de Giuseppe Gilberto Biondi, op. cit., p. 42: "così mentre il logos greco libera noeticamente l'uomo dal male indicandogli la via del bene e del vero, mentre il logos cristiano libera l'uomo sotericamente e dinamicamente facendosi "carne" e perdono, il logos senecano non può liberare e salvare l'uomo dal male ma solo indirizzarlo al bene: e solo la virtus può raggiungerlo". 
estranhas e poderosas forças. A magia de Medeia ${ }^{(19)}$, cujos encantamentos podem ter os mais maravilhosos efeitos, como inverter o curso das estaçóes, cobrir a terra de flores em pleno verâo, ou proporcionar colheitas em pleno Inverno ${ }^{(20)}$, indicia, prolonga e acentua o ambiente irracional, avesso aos contornos e à natureza da razáo. $\mathrm{Na}$ tragédia homónima, a extraordinária manifestaçăo dos poderes de Medeia encontra-se, privilegiadamente, no episódio em que prepara o manto que oferecerá a Creúsa ${ }^{(21)}$. A efectivaçăo dos poderes mágicos aparece associada aos poderes $\mathrm{e}$ às entidades invocados; aí, depois de invocar o Caos obscuro e as trevas infernais, invoca Hécate e os desregrados e castigados Ixíon, Tântalo, Sísifo e as Danaides. Estas invocaçōes, porém, repetem parcialmente as invocaçōes presentes no prólogo e este é já suficiente para delinear a marginalidade furiosa de Medeia. Nas imprecaçóes do prólogo, o coração e as mãos de Medeia projectam-se já na morte da nova esposa, na extinção da linhagem do rei de Corinto, no miserável exílio de Jasâo ${ }^{(22)}$. Como funesto augure que imola as vítimas nos altares consagrados, também ela deve observar e perscrutar nas entranhas - uma clara alusăo ao futuro infanticídio. É para este crime, abominável como nenhum outro até entăo se viu, que Medeia consente que a cólera lhe invada a alma e implora o concurso dos deuses. Selvagens, inauditos, horríveis, capazes de fazer tremer o céu e a terra, săo os males que abriga no seu espírito (effera ignota horrida, / tremenda caelo pariter ac terris mala / mens intus agitat) ${ }^{(23)}$. Tudo nela é já decisão, obsessão, fúria e desmando.

Não se pode dizer que esta furiosa disposiçăo de Medeia resulte da irrupção de algum elemento novo, até aí ausente, no comportamento da princesa da Cólquide. É certo que foi a consciência do eminente abandono de Jasáo que fez germinar nela este acto de vingança; os crimes, os actos ímpios e celerados, porém, há muito se enraizaram na memória, há muito que constituem a húmida corrente do seu hálito. $\mathrm{O}$ roubo do Velo de Oiro, a dilaceraçăo de um irmão, a dispersăo do seu cadáver pelas ondas do mar, o corpo de Pélias fervendo num vaso de bronze - este é o

(19) Sobre a magia de Medeia ver José António Segurado e Campos, "A magia de Medeia", in Aurora López / Andrés Pociña (eds), Medeas. Versiones de un mito desde Grécia hasta hoy, Granada, 2002, 2 vols., pp. 511-522, I vol. Nesta obra, encontram-se vários artigos sobre a Medeia de Séneca.

(20) Cf. vv. 759-761. A ediçăo por mim utilizada e citada é a de Otto Zwierlein, Oxford, 1986.

(21) Cf. vv. $740-848$

(22) Cf. vv. 1-55.

(23) Cf. vv. 45-47. 
lutuoso rasto deixado por Medeia ${ }^{(24)}$. O crime que se prepara para realizar năo é um acto isolado, é a continuaçăo da cadeia de crimes que a desordem e o vício avolumam e perpetuam. Aos olhos de Medeia, estes crimes têm o rosto do amor, de um infelix amor. Percebidos como uma dádiva que tem preço, como um penhor que constrange, como desvario cioso de reconhecimento, estes crimes são a imagem de um desfigurado amor, paixão feroz e insaciável, cadilho onde, numa continuada inversaão, se forja o ódio e a vingança de Medeia ${ }^{(25)}$. Na "lógica" do affectus que a domina, só o crime pode castigar o abandono de quem por crimes se juntou. "A casa ganha pelo crime, pelo crime deve ser abandonada" (26).

Os excessos das paixōes, todavia, nāo inflamam apenas Medeia. Pela lascívia, pela luxúria do poder ou pelo medo, de um modo ou de outro, as personagens da Medeia estão sob o império das paixóes ${ }^{(27)}$. Apesar de supor afastada de si a tirania e de ver no casamento de sua filha Creúsa com Jasăo, perseguido por Acaste, sinais da sua benevolência, a verdade é que, não apenas no facto de patrocinar esse casamento, como também no modo rude com que trata Medeia - o seu primeiro ímpeto é condená-la à morte -, Creonte deixa transparecer sinais de arrogância e prepotência. Ao vê-la aproximar-se de si, pretende antes de mais forçá-la ao silêncio, fazê-la finalmente aprender a dobrar-se à autoridade de um rei. A autoridade que o rei quer impor nāo parece basear-se na razāo e na justiça, uma vez que, como ele proclama, justo ou injusto, Medeia deve curvar-se ao poder do rei ${ }^{(28)}$.

Os excessos de Jasăo sâo óbvios ${ }^{(29)}$. Embora o procure negar ${ }^{(30)}$, ele foi o cúmplice de um caminho de desvarios e os crimes de Medeia, como ela reclama, são também os seus; mais do que isso, foi na teia dos seus interesses que ganharam forma e sopro. Um facto, todavia, ganha relevo na caracterizaçāo de Jasāo: ele é um dos membros, é o comandante dos Argonautas que partiram em busca do Velo de Oiro. Pertencer ao grupo dos marinheiros que a bordo da Argo rasgou os mares, significa partilhar uma

(24) Cf. vv. 129-136; 465-476.

(25) Cf. vv. 397 ss.

(26) "quae scelere parta est, scelere linquenda est domus." Cf. v. 55.

(27) Até a ama, pela natureza dos seus conselhos e pela inquietação que a perpassa năo escapa a este juizo. Ver vv. 150-178.

(28) "Aequum atque iniquum regis imperium feras." Cf. v. 195. Ver vv. 179-300.

(29) O Coro diz de Jasấo que pela primeira vez toma uma măo com o consentimento dos sogros. Cf. vv. 102-106.

(30) Cf. vv. 498-499. 
aventura marcada inicialmente pelo excesso e fela desmedida, uma vez que, como o Coro afirma ${ }^{(31)}$, a viagem desta nau, ultrapassando todos os antigos limites, năo só marca o fim da inocência e a emergência da ambiçăo, como assinala a quebra do equilíbrio da natureza e a violaçăo da ordem reinante. Desta forma, logo no início da expediçāo, está Jasăo marcado, ab origine, por uma bybris que o acompanhará nesta aventura. Não espanta que da recompensa desta viagem faça parte Medeia, flagelo mais agudo que o mar ${ }^{(32)}$. A aproximaçấo entre a desarmonia provocada pela Argo e as faltas cometidas por Jasāo, sugerindo uma reversibilidade de culpas e crimes, ilustra a dimensāo cósmica da desordem instaurada. Os crimes efectuados, ainda que por măos singulares, năo se confinam à esfera individual, têm repercussōes cósmicas e reflectem-se nos fenómenos da natureza. Neste contexto, é oportuno sublinhar a continuidade e a implicaçăo entre os actos humanos e a ordem da natureza; o crime individual projecta-se no desregramento sócio-político e este, numa continuidade de sentido, na fractura da ordem que regula a natureza ${ }^{(33)}$ - em última análise săo movimentos divergentes ao Logos que governa o real.

O cenário desenhado, onde as personagens evoluem em desvairadas paixổes, é, pois, de excessos e crimes. E contudo, não seria difícil descobrir outra semente de tragédia, uma situaçáo aberta ao trágico, situaçăo que, nẩo estando fora do contexto da furiosa paixão de Medeia, dela se distanciava, podendo constituir um tema autónomo de tragédia. No monólogo que precede o diálogo com Medeia ${ }^{(34)}$, Jasẩo olha-se como homem dilacerado por um conflito: ele encontra-se entre as terríveis ameaças de Acaste, rei de Iolco, que sobre ele pretende vingar a morte de seu pai, Pélias, e o poder do rei de Corinto, Creonte, que, tendo-o escolhido para genro, o leva a atraiçoar as promessas outrora feitas a Medeia. A confrontaçăo com Creonte, que o acolheu na fuga ao rei dos Iolcos, significa perder-se a si, a Medeia, aos filhos, e é a estes que, sobretudo, deve proteger - o pai deve impor-se ao marido. Jasão está entre dois males, numa constrangedora situaçáo que năo tem saída, nem conciliação possível. Jasāo está entre dois reis:

(31) Cf. vv. 302-379; 579-669.

(32) Cf. vv. 360-364.

(33) Recordemos que, segundo os estóicos, o cataclismo que, sob a forma de dilúvio ou de conflagraçăo, conduziria o mundo ao caos inicial, acompanha o crescente desregramento moral do comportamento humano.

(34) Pode ver-se neste monólogo uma espécie de sententia acerca das infelicidades e os seus remédios (ver Charles Guittard, Sénèque. Médèe, Paris, Flammarion, 1997, p. 59, nota 3); tal facto năo anula a semente de tragicidade aqui presente. 
IA. Quid, misera, meque teque in exitium trahis?

Abscede, quaeso. ME. Supplicem audiuit Creo.

LA. Quid facere possim, loquere. ME. Pro me uel scelus.

IA. Hinc rex et illinc-ME. Est et his maior metus

Medea. (35)

Esta semente de conflito, promessa e ameaça de tragédia, é, no entanto, pouco mais do que aflorada no texto, sendo imediatamente coberta pelo temível furor de Medeia que tudo subordina e ofusca. Medeia nāo é uma tragédia do conflito, é uma tragédia da fúria da paixăo amorosa. Tudo converge e se concentra na vingança delineada no prólogo e por fim realizada. Para castigo de Jasão, Medeia sacrificará os filhos porque, contra tudo e por todos abandonada, a Medeia restará ainda a força violenta de Medeia:

ME. Medea superest: hic mare et terras uides ferrumque et ignes et deos et fulmina. ${ }^{(36)}$

Enquanto medita e projecta a concretização do infanticídio, Medeia năo é alheia a hesitaçōes e escrúpulos ("quid, anime, cessas?"; "quid, anime, titubas"; "cede pietate, dolor." (37)), como se a antecipaçăo do horror do acto the pudesse impor um freio ao seu ímpeto e a exortasse a abrandar e a limitar a sua vingança. As hesitaçóes têm, porém, curta vida porque mal afloram são imediatamente submergidas na torrente vulcânica do ódio, do ciúme, da vingança ("incumbe in iras"; "ira, qua ducis, sequor." ${ }^{(38)}$ ), e o que resulta desse apressado sobressalto moral é o reforço da sua ira e a consequente acrescida determinaçâo em cometer o crime inaudito. Entâo, exultando na alegria dos crimes praticados, o roubo do Velo de Ouro, o desmembramento do irmâo, o patrocínio da morte de Pélias às máos das suas próprias filhas, Medeia deleita-se agora na ideia do celerado acto ${ }^{(39)}$,

(35) Cf. vv. 513-517.

IA. Por que razăo, infeliz, me arrastas, a mim e a ti, para a ruína?

Parte, peço-te. ME. Creonte ouviu a minha súplica.

IA. Que posso fazer, diz-me. ME. Por mim, um crime.

LA. Estou entre este e o outro rei - ME. Ainda de maior medo é motivo Medeia.

(36) Cf. vv. 166-167.

ME. Resta ainda Medeia: nela vês o mar e a terra

e a espada e o fogo e os deuses e os raios.

(37) Cf. vv. 895, 937, 944, respectivamente. Para as hesitaçōes de Medeia ver vv. 893-977

(38) Cf. vv. 902-953.

(39) Cf.. vv. 910-915. 
crime hediondo e estranho às leis dos deuses e à consciência moral. A presença das Fúrias, a entrevista sombra do irmão, mais năo fazem do que vincar o estado de delirante transgressăo. As hesitaçōes de Medeia sāo, porém, significativas no desenvolvimento do drama, pois mostram a consciência com que age e a débil vontade exercitada. Da consciência dos males e do falhanço da vontade, assim fundamente comprometida na acção, resulta, inequívoca e irremissível, a aumentada culpa de Medeia ${ }^{\left({ }^{(60)} \text {. }\right.}$

Uma excepçáo pode ser apontada no desenrolar destas exacerbadas paixóes: as intervençōes do Coro. Pelos votos solares e positivos que profere na primeira intervençăo - a intervençăo assume a forma de um epitalâmio -, pela crítica à violência, ao furor e aos actos orgulhosos que anima as suas segunda e terceira apariçōes, o Coro diverge das personagens, indicando um caminho oposto ao por elas seguido, marcando o contraponto das paixóes e recortando, pelas suas palavras, uma sabedoria de natureza inversa ao delírio de Medeia. Ao distanciar-se das paixôes, as intervençōes do Coro incentivam o espectador a assumir uma atitude crítica, o que, em última análise, corresponde à intenção pedagógica do teatro de Séneca.

\section{A MEDELA DE SÉNECA: UMA TRAGÉDIA PARA A VIRTUDE}

Estamos agora em condiçóes de responder à outra pergunta que acima colocámos. Afinal, como compreender que um homem tảo preocupado com a virtude componha tragédias cujas personagens constituem uma autêntica galeria de celerados e as suas acçôes uma colecçấo de crimes desencadeados por desenfreadas paixōes? Qual o alcance pedagógico deste teatro? Como se liga Medeia à virtude? Pela restante obra, pelas afirmaçōes espalhadas ao longo das Epistolae, pela dominante aspiraçăo a uma vida virtuosa e pela recusa de uma estética que a ela năo conduza, não se pode pôr em causa a vocaçáo pedagógica e moral do teatro de Séneca ${ }^{(41)}$. Dados os contornos desregrados da acção dramática, năo é pela apresentaçăo de exemplos considerados como modelos a seguir que a intenção pedagógica se concretiza ${ }^{(42)}$; esta realiza-se também pelos exemplos, mas, ao contrário,

(40) Para a culpa de Medeia ver ainda vv. 244 ss.

(41) Sobre a intençāo moralista c didáctica das tragédias de Séneca veja-se F. Giancotti, Saggio sulle tragedie di Séneca, Roma, 1953, particularmente o capítulo V.

(42) "Ecco perchè non vi sono in Seneca eroi positivi e le sue tragedie offrono una visione in negativo di tutti i suoi protagonisti (...)." Cf. Gianna Patrone, "Il disagio della 
mediante a apresentaçáo de exemplos que se situam nos antípodas da virtude, mediante personagens dominadas por paixōes, como se, assistindo ao carrocel de vícios que pela cena passa, pudesse o espectador compreender a lógica interna das paixôes e o inevitável fim a que conduzem (no contexto político da imperial Roma de Nero, podemos perceber ainda melhor o alcance didáctico desta pretensão). Como o ilustra e o sofre Medeia ${ }^{(43)}$, as paixóes colocam-nos sempre sob o jugo da inconstante Fortuna, deixando-nos à mercê de contingências que năo podemos nem prever, nem controlar, e por isso escravizando-nos. $\mathrm{O}$ resultado deste processo só pode ser trágico.

A primeira certeza que emana desta representação das paixổes é que em nenhuma circunstância poderăo elas trazer alguma coisa de bom, alguma consequência benéfica, sendo portanto ilusória a ideia de que é possível adocicá-las ou com elas manter uma suave permissividade. A paixāo é sempre um pórtico para o vício. Nestas circunstâncias, nāo apenas o pathos trágico surge desvalorizado, uma vez que só por distorção se poderá falar de nobreza ou de imerecimento do sofrimento, como também se requer, condição primeira desta pedagogia, uma fractura na relaçâo de identificaçáo entre o espectador e a personagem. No caminho inverso a esta identificaçāo, o teatro de Séneca exige uma ruptura entre personagem e espectador, ruptura que abra uma distância crítica entre o que se vê e o que se pensa. Por esta razão nāo é objectivo da tragédia estóica suscitar o terror e a piedade ou purificar estas emoçóes; em seu lugar, o que se reclama do espectador é uma atitude reflexiva, um distanciamento que faça com que daqueles sombrios exemplos mostrados germine a conduta virtuosa. O trabalho do poeta deve, pois, prolongar-se no comentário filosófico; sem ele a tragédia é um desenrolar de crimes que suscitarăo perplexidade e até uma má influência. Só a recolha do horror visto e a sua metamorfose no contrário, mediante a reflexăo filosófica, podem completar os desígnios pedagógicos. Da visāo de Medeia furiosa, ciumenta e vingativa desprende-se, afinal, o recorte contrário de uma imaginada Medeia serenamente doce na ressonância de uma alegre sabedoria.

forma: la tragedia negata di Séneca", Dioniso, LII, 1981, pp. 357-367 (para este passo ver p. 361). Acrescente-se que o volume onde está publicado este artigo, constituindo as Atti dell' VIII Congresso Internazionale di Studi sul Dramma Antico, Siracusa, 9-12 de settembre de 1981, é inteiramente dedicado a "Seneca e il teatro".

(43) Para a sofrida consciência das mudanças da Fortuna ver, por exemplo, vv, 217-220. 